ARTICLE

Received 15 May 2013 | Accepted 19 Jun 2013 | Published 15 Jul $2013 \quad$ DOl: 10.1038/ncomms3167

\title{
Gold peroxide complexes and the conversion of hydroperoxides into gold hydrides by successive oxygen-transfer reactions
}

\author{
Dragoş-Adrian Roşca ${ }^{1}$, Joseph A. Wright ${ }^{1}$, David L. Hughes ${ }^{1} \&$ Manfred Bochmann ${ }^{1}$
}

Gold catalysts are widely studied in chemical and electrochemical oxidation processes. Computational modelling has suggested the participation of $\mathrm{Au}-\mathrm{OO}-\mathrm{Au}, \mathrm{Au}-\mathrm{OOH}$ or $\mathrm{Au}-\mathrm{OH}$ surface species, attached to gold in various oxidation states. However, no structural information was available as isolable gold peroxo and hydroperoxo compounds were unknown. Here we report the syntheses, structures and reactions of a series of gold(III) peroxides, hydroperoxides and alkylperoxides. The Au-O bond energy in peroxides is weaker than in oxides and hydroxides; however, the $\mathrm{Au}-\mathrm{OH}$ bond is also weaker than $\mathrm{Au}-\mathrm{H}$. Consequently $\mathrm{Au}-\mathrm{OH}$ compounds are capable of oxygen-transfer generating gold hydrides, a key reaction in a water splitting cycle and an example that gold can react in a way that other metals cannot. For the first time it has become possible to establish a direct connection from peroxides to hydrides: $\mathrm{Au}-\mathrm{OO}-\mathrm{Au} \rightarrow \mathrm{Au}-\mathrm{OOH} \rightarrow \mathrm{Au}-\mathrm{OH} \rightarrow \mathrm{Au}-\mathrm{H}$, via successive oxygen-transfer events.

\footnotetext{
${ }^{1}$ Wolfson Materials and Catalysis Centre, School of Chemistry, University of East Anglia, Norwich NR4 7TJ, UK. Correspondence and requests for materials should be addressed to M.B. (email: m.bochmann@uea.ac.uk).
} 
G old-based oxidation catalysts have been the subject of detailed investigations for over 20 years, ever since the first report of $\mathrm{CO}$ oxidation by supported gold nanoparticles ${ }^{1-4}$. The mode of oxygen activation remains unclear, not least as $\mathrm{Au}-\mathrm{O}$ bonds are thought to be intrinsically weak and in general thermally unstable ${ }^{5}$, and the surfaces of gold catalysts adsorb $\mathrm{O}_{2}$ only to a very limited extent ${ }^{6}$. It has been proposed that negatively charged gold nanoclusters facilitate $\mathrm{O}_{2}$ adsorption by electron transfer to give surface superoxo-like species ${ }^{4-12}$, whereas Gates and co-workers ${ }^{13}$, and Hutchings et al. ${ }^{14}$, showed that high-activity gold catalysts for $\mathrm{CO}$ oxidation contain species in higher oxidation states $\left(\mathrm{Au}^{+}, \mathrm{Au}^{3+}\right)$. A very recent study postulated that $\mathrm{Au}^{3+}$ peroxides and oxides are key intermediates in the electrochemical water splitting on gold electrodes ${ }^{15}$. A number of computational studies modelling oxidation reactions envisage the formation and interconversion of species with $\mathrm{Au}-\mathrm{O}-\mathrm{O}-\mathrm{Au}, \mathrm{Au}-\mathrm{OOH}$ and $\mathrm{Au}-\mathrm{O}-\mathrm{Au}$ linkages ${ }^{16-18}$. To-date, there is, however, very little precise information available on the structures and bonding of such species; and although a number of gold oxo and hydroxo complexes have been reported ${ }^{5}$, such as the well-known cations $\left[(\mathrm{LAu})_{3}(\mu-\mathrm{O})\right]^{+}$and $\left[(\mathrm{LAu})_{2}(\mu-\mathrm{OH})\right]^{+}$ $(\mathrm{L}=\text { phosphine or carbene })^{19-22}$ or the gold(III) oxo compounds $\left[\left\{\left(\mathrm{C}^{\wedge} \mathrm{N}^{\wedge} \mathrm{N}\right) \mathrm{Au}_{2}(\mu-\mathrm{O})\right]^{2+}\right.$ and $\left[(\mathrm{bipy})_{2} \mathrm{Au}_{2}(\mu-\mathrm{O})_{2}\right]^{2+}$ (where $\mathrm{C}^{\wedge} \mathrm{N}^{\wedge} \mathrm{N}$ represents a tridentate cyclometallated 6-benzyl-2, $2^{\prime}$-bipyridyl and bipy a substituted $2,2^{\prime}$-bipyridy ${ }^{23-31}$ ), to the best of our knowledge isolable peroxo, hydroperoxo and alkylperoxo complexes of gold (in any oxidation state) were unknown.

We found recently that $\mathrm{C}^{\wedge} \mathrm{N}^{\wedge} \mathrm{C}$ pincer ligands based on the dianionic 2,6-diphenylpyridine framework are capable of stabilizing a number of novel gold(III) compound types ${ }^{32,33}$, including the first examples of gold(III) hydrides and olefin complexes ${ }^{34,35}$. Given the importance of oxygen ligands in oxidations as well as water cleavage reactions, we decided to explore the reactivity of such gold(III) pincer complexes towards oxygen ligands, including possible $\mathrm{Au}-\mathrm{O} \leftrightarrow \mathrm{Au}-\mathrm{H}$ interconversions. We report here the formation and structures of a series of gold(III) compounds with $\mathrm{O}^{2-}, \mathrm{O}_{2}^{2-}, \mathrm{HOO}^{-}$and $\mathrm{ROO}^{-}$ligands, the nature of the $\mathrm{Au}-\mathrm{O}$ bond in these compounds and their reactivity as oxidants, and we show that, unlike other metal hydroxides, a gold(III) hydroxide is readily converted into the corresponding gold hydride by oxygen-transfer, a step relevant to the water splitting cycle.

\section{Results}

Synthesis and characterization. The reaction of the pincer complex $\left(\mathrm{C}^{\wedge} \mathrm{N}^{\wedge} \mathrm{C}\right) \mathrm{AuOH} \quad(\mathbf{1})^{31} \quad\left\{\left(\mathrm{C}^{\wedge} \mathrm{N}^{\wedge} \mathrm{C}\right)=\left[2,6-\left(\mathrm{C}_{6} \mathrm{H}_{3}{ }^{t} \mathrm{Bu}-\right.\right.\right.$ $\left.{ }_{4}\right)_{2}$ pyridine $]^{2-}$ \} with $t$-butyl hydroperoxide in toluene at room temperature results in water elimination and formation of $\left(\mathrm{C}^{\wedge} \mathrm{N}^{\wedge} \mathrm{C}\right) \mathrm{AuOO}^{t} \mathrm{Bu}(2)$, which was isolated as yellow crystals. An analogous reaction of 1 with an excess of $30 \%$ aqueous hydrogen peroxide in toluene rapidly leads to the precipitation of the hydroperoxide 3, which was isolated as a yellow powder (Fig. 1). Unlike 1, compound 3 is only sparingly soluble in toluene. Although the ${ }^{1} \mathrm{H}$ NMR spectra of $\mathbf{1}$ and $\mathbf{3}$ are very similar, freshly prepared samples of $\mathbf{3}$ show an $\mathrm{OH}$ resonance at $\delta$ $8.26\left(\mathrm{CD}_{2} \mathrm{Cl}_{2}\right)$, which is not detectable for the hydroxide $\mathbf{1}$. Over longer periods of time in $\mathrm{CD}_{2} \mathrm{Cl}_{2}$ or THF solutions, the ${ }^{1} \mathrm{H}$ NMR pattern transforms into that of a new compound, identified as the bridging peroxide $\left(\mathrm{C}^{\wedge} \mathrm{N}^{\wedge} \mathrm{C}\right) \mathrm{AuOOAu}\left(\mathrm{C}^{\wedge} \mathrm{N}^{\wedge} \mathrm{C}\right)(4)$, which can be isolated as yellow crystalline blocks. The condensation is quite facile and recrystallization attempts of 3 repeatedly gave 4 instead. The condensation reaction is, however, reversible, and keeping 4 in water-saturated $\mathrm{CD}_{2} \mathrm{Cl}_{2}$ solutions regenerated $\mathbf{1}$ and 3 . Treatment with dry solvents (acetone or THF) also induces the dehydration of the hydroxide 1 to give the bridging oxide complex 5. The process is reversible, and exposure of $\mathbf{5}$ to moisture regenerates $\mathbf{1}$.

Unlike the hydroperoxide $\mathbf{3}$, the tert-butylperoxide $\mathbf{2}$ and bridging peroxide 4 were found to be remarkably temperature stable. Heating THF solutions of $\mathbf{2}$ and $\mathbf{4}$ for $16 \mathrm{~h}$ at $60^{\circ} \mathrm{C}$ leaves the compounds unchanged. Complexes $\mathbf{2}$ and $\mathbf{4}$ are also stable to

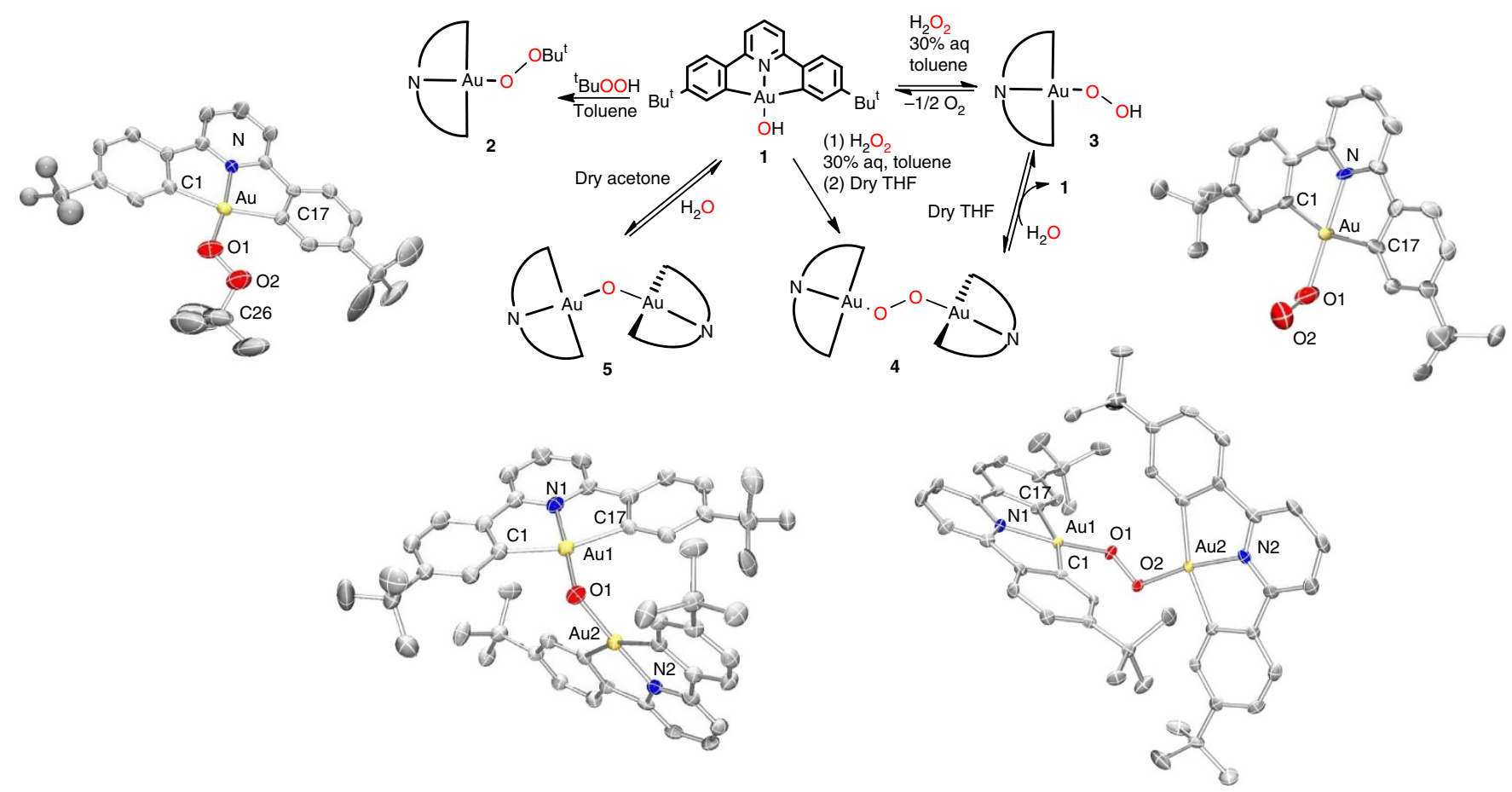

Figure 1 | Syntheses pathways of gold(III) peroxide and oxide complexes. Synthesis pathways showing the molecular structures of $\left(C^{\wedge} N^{\wedge} C\right) A u O O^{\dagger} B u$ (2), $\left(\mathrm{C}^{\wedge} \mathrm{N}^{\wedge} \mathrm{C}\right) \mathrm{AuOOH}(\mathbf{3}),\left(\mathrm{C}^{\wedge} \mathrm{N}^{\wedge} \mathrm{C}\right) \mathrm{AuOOAu}\left(\mathrm{C}^{\wedge} \mathrm{N}^{\wedge} \mathrm{C}\right)(\mathbf{4})$ and $\left(\mathrm{C}^{\wedge} \mathrm{N}^{\wedge} \mathrm{C}\right) \mathrm{AuOAu}\left(\mathrm{C}^{\wedge} \mathrm{N}^{\wedge} \mathrm{C}\right)(\mathbf{5})$ determined by $\mathrm{X}$-ray diffraction. Ellipsoids are set at $50 \%$ probability. Hydrogen atoms are omitted for clarity. 
Table 1 | Comparison of geometric parameters of gold(III) peroxide and oxide complexes.

\begin{tabular}{|c|c|c|c|c|}
\hline & $\left(C^{\wedge} N^{\wedge} C\right) A u O O^{t} B u(2)$ & $\left(C^{\wedge} N^{\wedge} C\right) A u O O H(3)^{\star}$ & {$\left[\left(\mathrm{C}^{\wedge} \mathrm{N}^{\wedge} \mathrm{C}\right) \mathrm{AuO}_{2}(\mathbf{4})\right.$} & {$\left[\left(\mathrm{C}^{\wedge} \mathrm{N}^{\wedge} \mathrm{C}\right) \mathrm{Au}\right]_{2} \mathrm{O}(5)$} \\
\hline Au1-O & $1.983(4)$ & $2.092(10)$ & $1.975(3)$ & $1.992(5)$ \\
\hline Au2-O & & & $1.977(3)$ & $1.989(5)$ \\
\hline $\mathrm{N}-\mathrm{Au}$ & $1.985(4)$ & $2.045(8)$ & $2.001(4)$ & $1.993(6)$ \\
\hline N-Au1-O & $172.84(17)$ & $178.8(4)$ & $170.92(15)$ & $177.2(2)$ \\
\hline Au1-O1-O2 & $115.4(3)$ & $111.9(8)$ & $116.0(2)$ & \\
\hline $\mathrm{Au}-\mathrm{O}-\mathrm{Au}$ & & & & $113.5(2)$ \\
\hline
\end{tabular}

${ }^{*}$ Crystals of $\mathbf{3}$ suffered from modest quality, possible twinning. Data for only 1 of 2 independent molecules shown.

ambient laboratory light giving no obvious signs of decomposition. Alternative synthesis protocols have been described for late transition metal peroxides involving direct $\mathrm{O}_{2}$ insertions into metal-hydrogen ${ }^{36-38}$, metal-carbon ${ }^{39,40}$ or metal-metal ${ }^{41}$ bonds. However, these insertion routes proved to be unsuitable for the synthesis of the gold peroxides, and the reaction of the gold(III) hydride $\left(\mathrm{C}^{\wedge} \mathrm{N}^{\wedge} \mathrm{C}\right) \mathrm{AuH}$ or the gold(II) dimer $\left(\mathrm{C}^{\wedge} \mathrm{N}^{\wedge} \mathrm{C}\right) \mathrm{Au}-$ $\mathrm{Au}\left(\mathrm{C}^{\wedge} \mathrm{N}^{\wedge} \mathrm{C}\right)^{34}$ with 1 atmosphere of dioxygen under either thermal or photolytic conditions failed to give $\mathbf{3}$ or $\mathbf{4}$, respectively.

The $\mathrm{O}-\mathrm{O}$ stretching vibration of peroxides $\mathbf{2 - 4}$ was examined by infrared (IR) spectroscopy. The IR spectrum of the hydroperoxide 3 is very similar to the hydroxide $\mathbf{1}$ but shows an additional band at $825 \mathrm{~cm}^{-1}$ (ref. 42), while the tert-butylperoxide 2 and the $\left(\mu-\kappa^{1}: \kappa^{1}\right.$-peroxo)digold complex 4 show three vibrational modes in the $\mathrm{O}-\mathrm{O}$ stretching region, at $831,844,878$ and 823,828 and $844 \mathrm{~cm}^{-1}$, respectively. For comparison, the $\mathrm{O}-\mathrm{O}$ stretching frequency in $\mathrm{H}_{2} \mathrm{O}_{2}$ is observed at $866 \mathrm{~cm}^{-1}$ (ref. 43), while a study on gold nanocluster catalysts by Yeo et al. ${ }^{44}$ assigned a Raman band at $820 \mathrm{~cm}^{-1}$ to a surface-bound $\mathrm{OOH}$ species.

The solid-state structures of $\mathbf{2 - 5}$ were determined by X-ray diffraction (Fig. 1). Pertinent geometric parameters are collected in Table 1. All complexes have $\mathrm{Au}-\mathrm{O}$ distances of 1.971(4)2.092(8) $\AA$. The O-O bond distances in 2 and 4 (1.416(6)$1.448(4) \AA$ ) are within the typical range of distances recorded for coordinated peroxo moieties ${ }^{36-41}$ and are closely comparable to that in $\mathrm{H}_{2} \mathrm{O}_{2}$. The oxide 5 has a bent structure, with an $\mathrm{Au}-\mathrm{O}-\mathrm{Au}$ angle of $113.5(2)^{\circ}$, as expected for an $\mathrm{sp}^{3}$-hybridized $\mathrm{O}$ atom. The results indicate negligible $\mathrm{Au}-\mathrm{O} \pi$-interactions; this aspect was subsequently confirmed by density functional theory (DFT) calculations (vide infra).

The peroxide complexes readily react with electrophiles. For example, 2 oxidized acetaldehyde to acetic acid, which then forms $\left(\mathrm{C}^{\wedge} \mathrm{N}^{\wedge} \mathrm{C}\right) \mathrm{AuOAc}(\mathbf{9})$, as confirmed by its independent synthesis, whereas 4 reacts with $\mathrm{Me}_{3} \mathrm{SiBr}$ to give $\left(\mathrm{C}^{\wedge} \mathrm{N}^{\wedge} \mathrm{C}\right) \mathrm{AuBr}$ and a 2:1 mixture of $\mathrm{Me}_{3} \mathrm{Si}-\mathrm{OO}-\mathrm{SiMe}_{3}$ and $\left(\mathrm{Me}_{3} \mathrm{Si}\right)_{2} \mathrm{O}$. The attempted formation of a superoxo complex by reacting $\left(\mathrm{C}^{\wedge} \mathrm{N}^{\wedge} \mathrm{C}\right) \mathrm{Au}\left(\mathrm{O}_{2} \mathrm{CCF}_{3}\right)$ with $\mathrm{KO}_{2}$ in a toluene/THF mixture (1:1) under an atmosphere of dioxygen led to the isolation of the crystallographically characterized furanolato complex $\left(\mathrm{C}^{\wedge} \mathrm{N}^{\wedge} \mathrm{C}\right) \mathrm{AuO}\left(\mathrm{C}_{4} \mathrm{H}_{7} \mathrm{O}\right) \mathbf{1 0}$ as a product of THF oxidation (Supplementary Fig. S1); this product was not formed in the absence of $\mathrm{O}_{2}$ (see Supplementary Methods).

Oxygen-transfer reactions. The ability of compounds $\mathbf{2}-\mathbf{5}$ to act as oxidizing agents was tested using $\mathrm{P}(p \text {-tolyl })_{3}$ as reductant. Treating the hydroperoxide 3 with the phosphine in $\mathrm{CD}_{2} \mathrm{Cl}_{2}$ solutions instantly led to the disappearance of the peroxo $\mathrm{OOH}$ resonance $\left(\delta\right.$ 8.26) and formation of $\mathrm{O}=\mathrm{P}(p \text {-tolyl })_{3}$ and $\mathbf{1}$, as observed by ${ }^{1} \mathrm{H}$ and ${ }^{31} \mathrm{P}\left\{{ }^{1} \mathrm{H}\right\}$ NMR spectroscopy. Similarly, treatment of the tert-butylperoxide 2 with one equivalent of

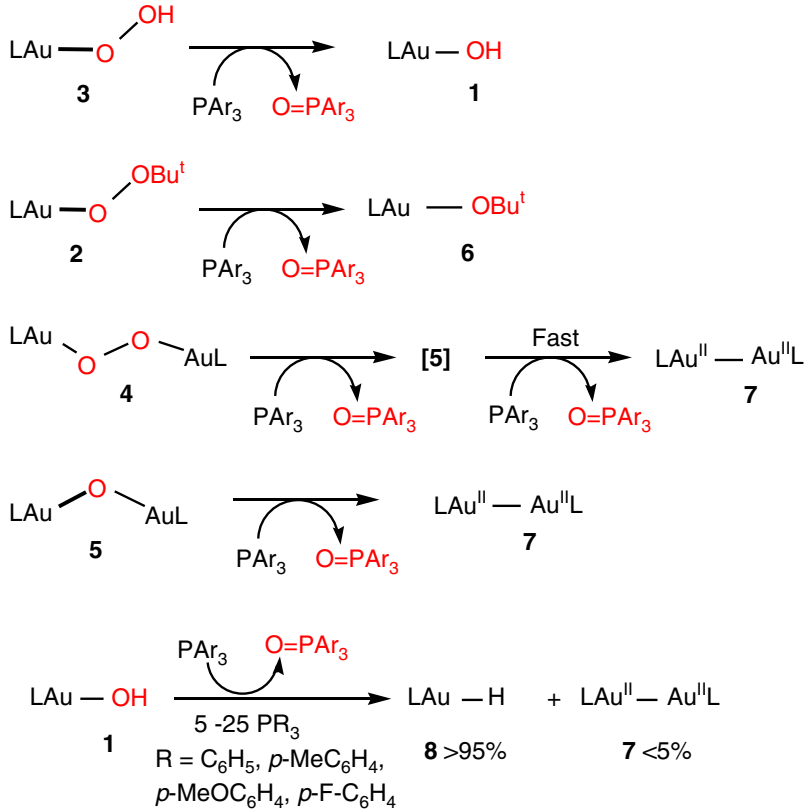

Figure 2 | Oxygen-transfer reactions of gold complexes. $L$ represents the dianionic $\mathrm{C}^{\wedge} \mathrm{N}^{\wedge} \mathrm{C}$ ligand shown in Fig. 1. $\mathrm{Ar}=p$-tolyl.

phosphine leads to the formation of the phosphine oxide together with $\left(\mathrm{C}^{\wedge} \mathrm{N}^{\wedge} \mathrm{C}\right) \mathrm{AuO}^{t} \mathrm{Bu}(6)$ (Fig. 2). The reaction was found to be much slower than in the case of $\mathbf{3}$ and full conversion was only reached after $16 \mathrm{~h}$. The identity of $\mathbf{6}$ was confirmed by its independent synthesis.

The binuclear peroxide complex 4 in $\mathrm{CD}_{2} \mathrm{Cl}_{2}$ oxidizes $\mathrm{P}(p \text {-tolyl })_{3}$ more slowly, with quantitative formation of $\mathrm{O}=\mathrm{P}$ $(p \text {-tolyl })_{3}$ after $36 \mathrm{~h}$. After $16 \mathrm{~h}$, the reaction mixture showed a number of gold products, including $4(21 \%),\left(\mathrm{C}^{\wedge} \mathrm{N}^{\wedge} \mathrm{C}\right) \mathrm{AuCl}$ $(17 \%)$ and the gold(II) dimer $\left(\mathrm{C}^{\wedge} \mathrm{N}^{\wedge} \mathrm{C}\right) \mathrm{AuAu}\left(\mathrm{C}^{\wedge} \mathrm{N}^{\wedge} \mathrm{C}\right)(7)(25 \%)$, as well as other unidentified products. Interestingly, the peroxide 4 and the gold(II) complex 7 co-exist in solution, that is, the peroxide is unable to oxidize $\mathrm{Au}(\mathrm{II})$ to the $\mathrm{Au}$ (III) oxide 5. We assume the reaction of $\mathbf{4}$ with phosphines proceeds by stepwise $\mathrm{O}$-abstraction, to give first the oxide 5. However, monitoring the reaction by ${ }^{1} \mathrm{H}$ NMR spectroscopy failed to show traces of $\mathbf{5}$, which suggests that the second reduction step to gold(II) is fast. The formation of $\mathrm{Au}(\mathrm{II})$ from the $\mathrm{Au}(\mathrm{III})$ oxide was confirmed independently by treating 5 with $\mathrm{P}(p \text {-tolyl })_{3}$ which cleanly gives 7 . The oxygen-transfer reactions of 1-5 are summarized in Fig. 2.

Hydroxide to hydride conversion. Carrying out the reduction of the hydroperoxide 3 with an excess of phosphine suggested the 
formation of an unexpected product, the hydride LAuH 8, which was readily identified by its high-field ${ }^{1} \mathrm{H}$ NMR signal at $\delta-6.5$ (in $\left.\mathrm{CD}_{2} \mathrm{Cl}_{2}\right)$. The same was observed when $\left(\mathrm{C}^{\wedge} \mathrm{N}^{\wedge} \mathrm{C}\right) \mathrm{AuOH}$ was reacted with an excess of phosphine. The formation of a gold hydride from a hydroxide was of interest as it represents a key step in a water splitting cycle.

The cleavage of water into hydrogen and oxygen remains a highly desirable goal in the search for alternatives to fossil fuels but continues to pose significant challenges ${ }^{45}$. Efforts to construct catalytic cycles for water cleavage rely on a detailed understanding of each mechanistic step, and for catalysts based on well-defined coordination complexes a number of mechanisms are operative $e^{46-48}$. For metals that can readily alter their oxidation states and undergo oxidative additions, the formation of a metal hydrido-hydroxide $\mathrm{M}(\mathrm{H})(\mathrm{OH})$ is a key step, as realized recently by Milstein et al. using ruthenium pincer complexes $\left[\mathrm{M}=2,6-\mathrm{C}_{5} \mathrm{H}_{3} \mathrm{~N}\left(\mathrm{CH}_{2} \mathrm{PBu}_{2}^{t}\right)\left(\mathrm{CH}_{2} \mathrm{NEt}_{2}\right) \mathrm{Ru}\right]^{49}$. On the other hand, an alternative and potentially simpler pathway is available that does not require changes in oxidation states (Fig. 3). This cycle involves the reaction of a metal cation with water to give a metal hydroxide. However, the key step in this scenario is the conversion of the metal hydroxide into a metal hydride. For most metals, the hydroxides are thermodynamically more stable than the hydrides, so that the $\mathrm{M}-\mathrm{OH} \rightarrow \mathrm{M}-\mathrm{H}$ transformation is not possible without an external hydride donor. The reaction of a metal hydroxide $\mathrm{M}-\mathrm{OH}$ generating a metal hydride by $\mathrm{O}$ abstraction has to the best of our knowledge not previously been observed.

A side reaction in the formation of $\left(\mathrm{C}^{\wedge} \mathrm{N}^{\wedge} \mathrm{C}\right) \mathrm{AuH}$ from $\left(\mathrm{C}^{\wedge} \mathrm{N}^{\wedge} \mathrm{C}\right) \mathrm{AuOH}$ is the $\mathrm{Au}(\mathrm{II})$ compound 7 ; this is, however, suppressed in a non-polar solvent such as toluene. The kinetics and mechanism of the oxygen-transfer from 1 was explored in the temperature interval from -10 to $-55^{\circ} \mathrm{C}$.

The reaction of 1 with an excess of $\mathrm{P}\left(\mathrm{C}_{6} \mathrm{H}_{4} \mathrm{X}-4\right)_{3}(\mathrm{X}=\mathrm{H}, \mathrm{Me}$, $\mathrm{OMe}, \mathrm{F})\left(5-25\right.$ molar equivalents) in toluene yields $\left(\mathrm{C}^{\wedge} \mathrm{N}^{\wedge} \mathrm{C}\right) \mathrm{AuH}$ (8) with high selectivity (see box in Fig. 2). As gold complexes can be light sensitive, and in order to suppress possible radical side reactions, all reactions were conducted in the dark.

To gain more insight into the reaction mechanism, the kinetics of the formation of $\mathbf{8}$ were followed by ${ }^{1} \mathrm{H}$ NMR spectroscopy (see Supplementary Figs S2-S6, Supplementary Table S1 and Supplementary Methods). The reaction is first-order in both gold and phosphine, $-\mathrm{d}[\mathbf{1}] / \mathrm{d} t=k[\mathbf{1}]\left[\mathrm{PR}_{3}\right]$. An Eyring plot over the temperature interval of -50 to $-10^{\circ} \mathrm{C}$ gave the activation parameters of the reaction as $\Delta H^{\ddagger}=-35.0(7) \mathrm{kJ} \mathrm{mol}^{-1}$ and $\Delta S^{\ddagger}=-105.7(2) \mathrm{J} \mathrm{mol}^{-1} \mathrm{~K}^{-1}$ (see Supplementary Figs S7-S9). The negative value of $\Delta S^{\ddagger}$ suggests that the reaction proceeds via an associative mechanism in the transition state.

The origin of the oxygen in the phosphine oxide was established using $\left(\mathrm{C}^{\wedge} \mathrm{N}^{\wedge} \mathrm{C}\right) \mathrm{Au}-{ }^{18} \mathrm{OH}\left(\mathbf{1}^{18}{ }^{18} \mathrm{O}\right)$. In the IR spectrum, the ${ }^{18} \mathrm{OH}$ vibration of $\mathbf{1 -}^{18} \mathrm{O}$ is shifted to lower energy by 20

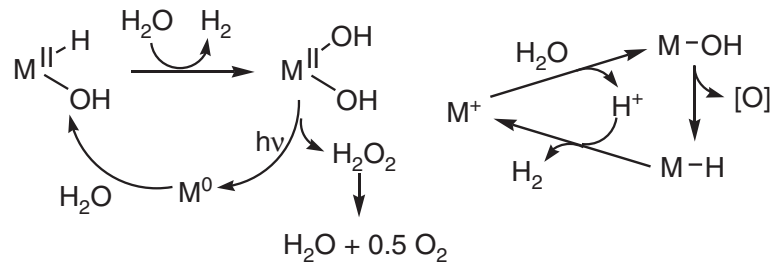

Figure 3 | Mechanisms of metal-mediated water cleavage. Although for ruthenium a redox mechanism involving $\mathrm{M}^{0}$ and $\mathrm{M}^{\mathrm{II}}(\mathrm{OH})_{2}$ intermediates has been demonstrated ${ }^{48}$, for other metals a non-oxidative pathway of water cleavage can be envisaged that involves a hydroxide-to-hydride transition. wavenumbers, to $3460 \mathrm{~cm}^{-1}$. Mass spectrometric analysis showed the formation of ${ }^{18} \mathrm{O}=\mathrm{P}(p \text {-tol })_{3}$ as the predominant product.

The reaction of the deuterated complex $\left(\mathrm{C}^{\wedge} \mathrm{N}^{\wedge} \mathrm{C}\right) \mathrm{AuOD}\left(\mathbf{1}-\boldsymbol{d}_{\mathbf{1}}\right)$ with $\mathrm{P}(p \text {-tol })_{3}$ at $253 \mathrm{~K}$ resulted in a kinetic isotope effect $k_{\mathrm{H}} / k_{\mathrm{D}}=1.45 \quad\left(\left[\left(\mathrm{C}^{\wedge} \mathrm{N}^{\wedge} \mathrm{C}\right) \mathrm{AuOH}(\mathrm{D})\right]_{0}:\left[\mathrm{P}(p \text {-tol })_{3}\right]_{0}=1: 10.8 ; \quad k_{\text {obs }}\right.$ $\left\{\left(\mathrm{C}^{\wedge} \mathrm{N}^{\wedge} \mathrm{C}\right) \mathrm{AuOH}\right\}=8.07(6) \times 10^{-4} \mathrm{~s}^{-1}, k_{\mathrm{obs}}\left\{\left(\mathrm{C}^{\wedge} \mathrm{N}^{\wedge} \mathrm{C}\right) \mathrm{AuOD}\right\}$ $\left.=5.49(3) \times 10^{-4} \mathrm{~s}^{-1}\right)$ (see Supplementary Fig. S10). A KIE of this magnitude is consistent with the involvement of an $\mathrm{O}-\mathrm{H}$ bending mode in the rate determining step ${ }^{50}$.

The electronic effect of the rate of hydride formation was explored by a Hammett correlation using phosphines with electron withdrawing and donating $p$-substituents ${ }^{51}$. There is a strong influence $\left(\rho=-3.15, R^{2}=0.94\right)$, with electron-donating groups such as $\mathrm{Me}$ or OMe substantially increasing the reaction rates (see Supplementary Figs S11, S12 and Supplementary Table 1). The negative $\rho$ value ( -1.05 per aryl ring) suggests that positive charge is built on the reaction centre and is in good agreement with a zwitterionic transition state.

The reaction rates are insensitive to the presence of radical inhibitors. No significant effect on the rate constants was observed when the reaction of $\left(\mathrm{C}^{\wedge} \mathrm{N}^{\wedge} \mathrm{C}\right) \mathrm{AuOH}$ with $\mathrm{P}(p \text {-tol })_{3}$ was carried in the presence or absence of TEMPO as radical scavenger $\quad($ TEMPO $=2,2,6,6$-tetramethyl-1-piperidyl- $N$-oxide). Galvinoxyl was found to react with the hydride $\mathbf{8}$ quantitatively giving 7. This implies that galvinoxyl is capable of $\mathrm{H}$-abstraction from $\left(\mathrm{C}^{\wedge} \mathrm{N}^{\wedge} \mathrm{C}\right) \mathrm{Au}-\mathrm{H}$ while TEMPO is not. As the bonddissociation energy (BDE) of TEMPOH is $291.34 \mathrm{~kJ} \mathrm{~mol}^{-1}$, while the $\mathrm{BDE}$ of galvinoxyl-H is $328.7 \pm 2.1 \mathrm{~kJ} \mathrm{~mol}^{-1}$, this provides an estimate of the $\mathrm{Au}-\mathrm{H}$ bond energy between these two values, which was confirmed by DFT calculations.

Quantum-chemical calculations. The structures and bonding of these complexes was further investigated by computational modelling using DFT methods (see Supplementary Data 1). Optimization of the gas phase geometries of compounds 1-5 allowed calculation of Au-O and $\mathrm{O}-\mathrm{O}$ bond energies (Table 2). The $\mathrm{Au}-\mathrm{O}$ bonds in the peroxides are significantly weaker than on the gold(III) oxide and hydroxide.

The O-O bonds weaken with increasing electron donation of the substituents. Similar effects were found for the $\mathrm{O}-\mathrm{O}$ bond strengths in the series $\mathrm{H}_{2} \mathrm{O}_{2}>\mathrm{MeOOH}>\mathrm{MeOOMe}(204,186$ and $158 \mathrm{~kJ} \mathrm{~mol}^{-1}$, respectively) ${ }^{52,53}$. A consideration of the molecular orbitals shows that the HOMOs do not show a consistent $\mathrm{Au}-\mathrm{O}$ bonding component, while the HOMO-1 orbitals show a variety of out-of-phase relationships between the oxygen lone pairs and the gold $d$-orbitals, that is, the interaction are anti-bonding (Fig. 4). This confirms the weak $\pi$-interactions between the metal and the oxygen ligands that was already suggested by the acute $\mathrm{Au}-\mathrm{O}-\mathrm{Au}$ and $\mathrm{Au}-\mathrm{O}-\mathrm{O}$ angles in the solid-state structures.

The calculated trends in BDEs confirm the experimental findings: the $\mathrm{Au}-\mathrm{H}$ bond is stronger than the $\mathrm{Au}-\mathrm{OH}$ bond, whereas for isoelectronic $\mathrm{Pt}(\mathrm{II})$ complexes the opposite trend is observed (Table 3).

\begin{tabular}{|c|c|c|c|c|c|}
\hline Compound & 1 & 2 & 3 & 4 & 5 \\
\hline $\mathrm{Au}-\mathrm{O}$ & 279 & 150 & 168 & 126 & 206 \\
\hline $\mathrm{AuO}-\mathrm{O}$ & - & 130 & 166 & 138 & - \\
\hline
\end{tabular}


a $\left(\mathrm{C}^{\wedge} \mathrm{N}^{\wedge} \mathrm{C}\right) \mathrm{AuOH} 1$

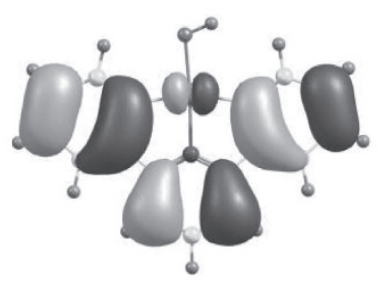

HOMO

C $\left(C^{\wedge} N^{\wedge} C\right) A u O O A u\left(C^{\wedge} N^{\wedge} C\right) 4$

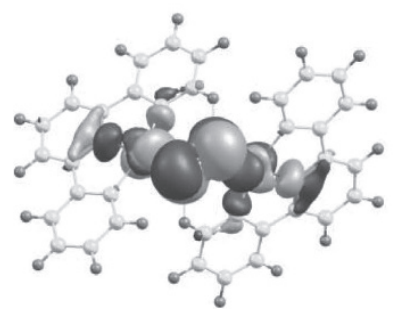

HOMO

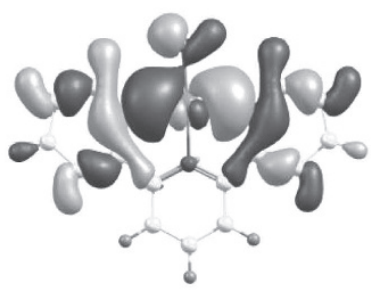

HOMO-1

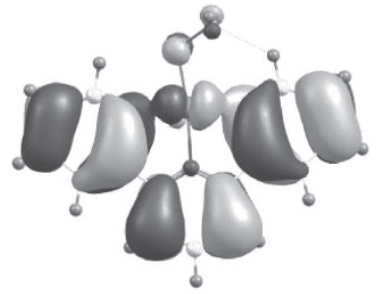

HOMO

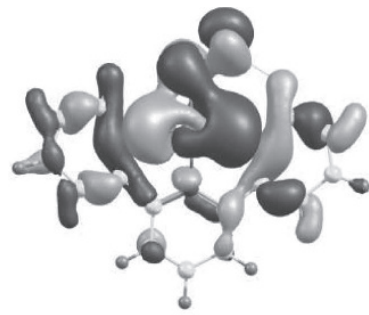

HOMO-1

\section{d $\left(C^{\wedge} N^{\wedge} C\right) A u O A u\left(C^{\wedge} N^{\wedge} C\right) 5$}

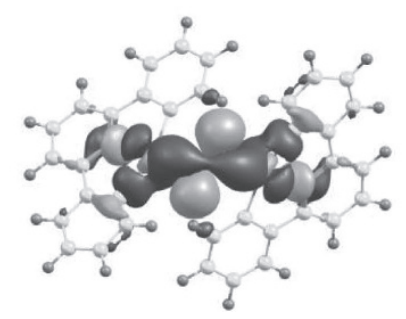

HOMO-1

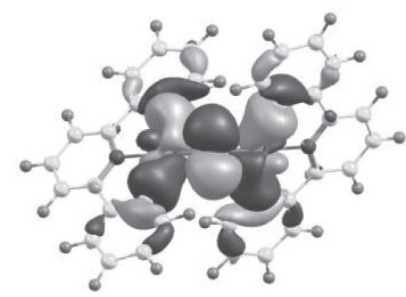

HOMO

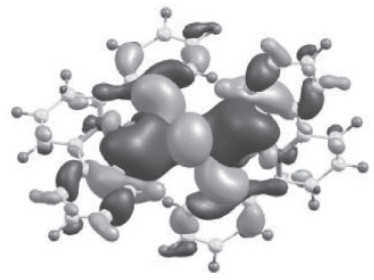

HOMO-1

Figure 4 | HOMO and HOMO-1 orbitals. HOMO and HOMO-1 orbitals of complexes 1 (a), 3 (b), 4 (c) and $\mathbf{5}$ (d). The HOMO-1 diagrams show out-ofphase relationships between the gold-centred and the oxygen orbitals, most clearly seen in the case of $\mathbf{1}$.

\section{Table 3 | Comparison of calculated and experimental bond- dissociation energies.}

\begin{tabular}{|c|c|c|c|}
\hline Complex & Calculated BDE & Diatomic compound & $\mathrm{BDE}^{\star}$ \\
\hline$\left(C^{\wedge} N^{\wedge} C\right) A u^{I I I}-H 8$ & 317 & $\mathrm{Au}-\mathrm{H}$ & $292 \pm 8$ \\
\hline$\left(\mathrm{C}^{\wedge} \mathrm{N}^{\wedge} \mathrm{C}\right) \mathrm{Au}^{\mathrm{III}}-\mathrm{OH} \mathbf{1}$ & 279 & $\mathrm{Au}-\mathrm{O}$ & 223 \\
\hline$\left(C^{\wedge} N^{\wedge} N\right) P^{\| I}-H$ & 350 & $\mathrm{Pt}-\mathrm{H}$ & 352 \\
\hline$\left(C^{\wedge} N^{\wedge} N\right) P^{\prime \prime \prime}-O H$ & 367 & Pt-O & 391 \\
\hline
\end{tabular}

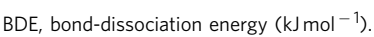

*Data from ref. 55.

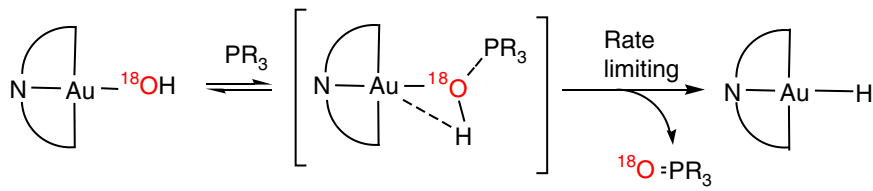

Figure 5 | Mechanistic pathway for the 0-abstraction from gold(III) hydroxide by phosphines. The observed kinetic isotope effect and DFT calculations support a concerted oxygen-transfer mechanism.

Attempts to computationally identify an intermediate in the reaction of $\mathrm{LAuOH}$ with $\mathrm{PR}_{3}$, such as a 5-coordinate phosphine adduct of the gold complex or a zwitterionic intermediate $\left[\left(\mathrm{C}^{\wedge} \mathrm{N}^{\wedge} \mathrm{C}\right) \mathrm{Au}^{(\delta-9}(\mu-\mathrm{OH})-\mathrm{PR}_{3}^{(\delta+)}\right]$ were unsuccessful. The results suggest a concerted mechanism for $\mathrm{O}$-abstraction by $\mathrm{PR}_{3}$ with simultaneous transfer of $\mathrm{H}$ from $\mathrm{O}$ to $\mathrm{Au}$, as would be represented by a bending mode of the $\mathrm{Au}-\mathrm{O}-\mathrm{H}$ moiety as $\mathrm{PR}_{3}$ approaches, in line with the observed modest kinetic deuterium isotope effect (Fig. 5).

\section{Discussion}

The isolation, structural characterization and reactivity studies of this series of gold complexes highlights that in a suitable ligand environment gold peroxide complexes are readily accessible. However, it has also become evident that the $\mathrm{Au}-\mathrm{O}$ bonds in peroxides are weaker than in oxides and hydroxides, that $\pi$-interactions in gold(III)-oxygen bonds are negligible, and that oxygen-transfer reactions are facile and well controlled. Surprisingly, even though the gold(II) complex supported by the pincer ligand used here possesses an unsupported $\mathrm{Au}-\mathrm{Au}$ bond and its reaction with $\mathrm{O}_{2}$ is calculated to be exothermic $\left(-136 \mathrm{~kJ} \mathrm{~mol}^{-1}\right)$, the complex fails to react with $\mathrm{O}_{2}$, and a route involving the hydroperoxide has to be used to access the anticipated binuclear gold peroxide. It remains to be established whether gold complexes can form side-on bonded $\mathrm{O}_{2}$ compounds of the type familiar for Group 10 metals and postulated as surface species in gold nanocluster catalysts. Experimental observations, supported by bond energy calculations, demonstrate that only in the case of gold is the conversion of metal hydroxide $\mathrm{M}-\mathrm{OH}$ into a hydride $\mathrm{M}-\mathrm{H}$ thermodynamically favourable, enabling a key step of the water splitting cycle to proceed. The stability of the $\mathrm{Au}-\mathrm{H}$ bond in $\left(\mathrm{C}^{\wedge} \mathrm{N}^{\wedge} \mathrm{C}\right) \mathrm{AuH}$ is in part a consequence of the $\mathrm{C}^{\wedge} \mathrm{N}^{\wedge} \mathrm{C}$ pincer ligand framework and the weak trans influence exercised by the pyridine donor. Oxygen-transfer from the gold hydroxide to phosphines proceeds in a concerted fashion, with bending of the $\mathrm{O}-\mathrm{H}$ bond toward the metal as the phosphine approaches. For the first time it could be shown that a succession of oxygen-transfer steps can provide a direct link between metal peroxides and metal hydride species, $\mathrm{Au}-\mathrm{OO}-\mathrm{Au} \rightarrow \mathrm{Au}-\mathrm{OOH} \rightarrow$ $\mathrm{Au}-\mathrm{OH} \rightarrow \mathrm{Au}-\mathrm{H}$.

\section{Methods}

General considerations. Unless stated otherwise, manipulations were performed using standard Schlenk techniques under dry nitrogen or a Saffron Scientific glovebox. Anhydrous solvents were freshly distilled from appropriate drying agents. $\left(\mathrm{C}^{\wedge} \mathrm{N}^{\wedge} \mathrm{C}\right) \mathrm{AuOH}\left\{\left(\mathrm{C}^{\wedge} \mathrm{N}^{\wedge} \mathrm{C}\right)=2,6-\left(\mathrm{C}_{6} \mathrm{H}_{3} \mathrm{Bu}^{t}-4\right)_{2}\right.$-pyridine dianion $\}$ was prepared using literature methods. Additional experimental details can be found in the Supplementary Information. 


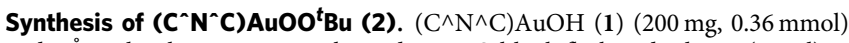
and $4 \AA$ molecular sieves were charged into a Schlenk flask and toluene $(20 \mathrm{ml})$ was added. ${ }^{\mathrm{t}} \mathrm{BuOOH}(5 \mathrm{M}$ in dodecane, $100 \mu \mathrm{l}, 0.5 \mathrm{mmol}$ ) was injected and the mixture was stirred at room temperature for $12 \mathrm{~h}$. The mixture was filtered and the volatile components were removed in vacuo. The solid residue was washed with light petroleum $(2 \times 5 \mathrm{ml})$ and dried under vacuum to give 2 as a yellow powder (180 mg, 80\%). Recrystallization from $\mathrm{CH}_{2} \mathrm{Cl}_{2}$ : light petroleum (1:1) at $-20^{\circ} \mathrm{C}$ gave 2 as yellow blocks. ${ }^{1} \mathrm{H}$ NMR $\left(300 \mathrm{MHz}, \mathrm{CD}_{2} \mathrm{Cl}_{2}\right) \delta 7.91\left(\mathrm{~d}, J=2 \mathrm{~Hz}, 2 \mathrm{H}, \mathrm{H}^{8}\right)$, $7.79\left(\mathrm{t}, J=8.0 \mathrm{~Hz}, 1 \mathrm{H}, \mathrm{H}^{1}\right), 7.49\left(\mathrm{~d}, J=8 \mathrm{~Hz}, 2 \mathrm{H}, \mathrm{H}^{5}\right), 7.38\left(\mathrm{~d}, J=8 \mathrm{~Hz}, 1 \mathrm{H}, \mathrm{H}^{2}\right)$, $7.28\left(\mathrm{dd}, J=8,2 \mathrm{~Hz}, 2 \mathrm{H}, \mathrm{H}^{6}\right), 1.40\left(\mathrm{~s}, 9 \mathrm{H}, \mathrm{OOCMe}_{3}\right), 1.36\left(\mathrm{~s}, 18 \mathrm{H}, \mathrm{C}^{11}\right)$ (see Supplementary Fig. S13). ${ }^{13} \mathrm{C}\left\{{ }^{1} \mathrm{H}\right\}$ NMR $\left(75 \mathrm{MHz}, \mathrm{CD}_{2} \mathrm{Cl}_{2}\right) \delta 170.80\left(\mathrm{C}^{9}\right), 164.41$ $\left(C^{3}\right), 154.96\left(C^{7}\right), 145.45\left(C^{4}\right), 142.42\left(C^{1}\right), 130.65\left(C^{8}\right), 124.82\left(C^{5}\right), 124.36\left(C^{6}\right)$, $116.30\left(\mathrm{C}^{7}\right), 79.68\left(\mathrm{OOCMe}_{3}\right), 35.75\left(\mathrm{C}^{10}\right), 31.33\left(\mathrm{C}^{11}\right), 26.49\left(\mathrm{OOCMe}_{3}\right)$. IR: 831, $844,878 \mathrm{~cm}^{-1}$. Anal. Calcd. (found) for $\mathrm{C}_{29} \mathrm{H}_{36} \mathrm{AuNO}_{2}$ : C, 55.50 (55.59); $\mathrm{H}, 5.78$ (5.80); N, 2.23 (2.34).

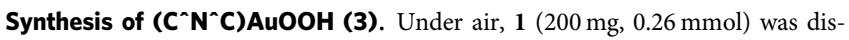
solved in toluene $(30 \mathrm{ml})$ and $\mathrm{H}_{2} \mathrm{O}_{2}(30 \%$ aq, $82 \mu \mathrm{l}, 0.52 \mathrm{mmol})$ was added. A yellow precipitate was immediately observed. The mixture was stirred for $30 \mathrm{~min}$ at room temperature, after which the supernatant was decanted and the yellow precipitate was washed with acetonitrile $(5 \mathrm{ml})$ and light petroleum $(5 \mathrm{ml})$ to afford 3 as a yellow powder ( $95.6 \mathrm{mg}, 65 \%$ ). Anal. Calcd. (found) for $\mathrm{C}_{25} \mathrm{H}_{28} \mathrm{AuNO}_{2}$ : C, 53.54 (52.91); H, 4.94 (4.80); N 2.45 (2.35). The elemental analysis was carried out on asprecipiatetd material; recrystallization attempts lead to contamination with the peroxide 4. ${ }^{1} \mathrm{H}$ NMR $\left(300 \mathrm{MHz}, \mathrm{CD}_{2} \mathrm{Cl}_{2}\right) \delta 8.26(\mathrm{~s}, 1 \mathrm{H}, \mathrm{OOH}), 7.83(\mathrm{t}, J=8 \mathrm{~Hz}$, $\left.1 \mathrm{H}, \mathrm{H}^{1}\right), 7.62\left(\mathrm{~d}, J=2 \mathrm{~Hz}, 2 \mathrm{H}, \mathrm{H}^{8}\right), 7.52\left(\mathrm{~d}, J=8 \mathrm{~Hz}, 2 \mathrm{H}, \mathrm{H}^{5}\right), 7.41(\mathrm{~d}, J=8 . \mathrm{Hz}$, $\left.2 \mathrm{H}, \mathrm{H}^{2}\right), 7.30\left(\mathrm{dd}, J=8,2 \mathrm{~Hz}, 2 \mathrm{H}, \mathrm{H}^{6}\right), 1.36\left(\mathrm{~s}, 18 \mathrm{H}, \mathrm{H}^{11}\right)$ (see Supplementary Fig. S14). ${ }^{13} \mathrm{C}$ data could not be obtained because of the degradation of $\left(\mathrm{C}^{\wedge} \mathrm{N}^{\wedge} \mathrm{C}\right) \mathrm{AuOOH}$ in solution. IR: $825 \mathrm{~cm}^{-1}$. Recrystallization from $\mathrm{CH}_{2} \mathrm{Cl}_{2}$ : light petroleum (1:1) at $+5^{\circ} \mathrm{C}$ overnight gave 3 as yellow blocks, which were analysed by X-ray diffraction.

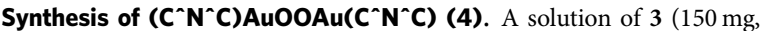
$0.25 \mathrm{mmol})$ in dry THF $(10 \mathrm{ml})$ was kept in the dark at room temperature. After 3 days, yellow crystalline blocks were observed. The supernatant was filtered off and the residue dried in vacuo, giving $\mathbf{4}$ as yellow crystals. An additional crop of crystals could be obtained by concentrating the mother liquor and leaving the solution to stand at room temperature. Total yield: $81 \mathrm{mg}, 55 \%$. The crystals obtained were suitable for X-ray diffraction. ${ }^{1} \mathrm{H}$ NMR $\left(300 \mathrm{MHz}, \mathrm{CD}_{2} \mathrm{Cl}_{2}\right) \delta 8.23(\mathrm{~d}, J=2 \mathrm{~Hz}, 2 \mathrm{H}$, $\left.\mathrm{H}^{8}\right), 7.80\left(\mathrm{t}, J=8 \mathrm{~Hz}, 1 \mathrm{H}, \mathrm{H}^{1}\right), 7.51\left(\mathrm{~d}, J=8 \mathrm{~Hz}, 2 \mathrm{H}, \mathrm{H}^{5}\right), 7.41\left(\mathrm{~d}, J=8 \mathrm{~Hz}, 1 \mathrm{H}, \mathrm{H}^{2}\right)$, $7.23\left(\mathrm{dd}, J=8,2 \mathrm{~Hz}, 2 \mathrm{H}, \mathrm{H}^{6}\right), 1.14\left(\mathrm{~s}, 18 \mathrm{H}, \mathrm{H}^{11}\right)$ (see Supplementary Fig. S15). $\left.{ }^{13} \mathrm{C}^{1}{ }^{1} \mathrm{H}\right\}$ NMR $\left(75 \mathrm{MHz}, \mathrm{CD}_{2} \mathrm{Cl}_{2}\right) \delta 170.14\left(\mathrm{C}^{9}\right), 163.45\left(\mathrm{C}^{3}\right), 154.41\left(\mathrm{C}^{\mathrm{f}}\right), 145.48$ $\left(C^{4}\right), 141.63\left(C^{1}\right), 129.99\left(C^{8}\right), 124.35\left(C^{5}\right), 123.71\left(C^{6}\right), 115.73\left(C^{7}\right), 35.27\left(C^{10}\right)$, $30.91\left(\mathrm{C}^{11}\right)$. IR: $823,828,844 \mathrm{~cm}^{-1}$. Anal. Calcd. (found) for $\mathrm{C}_{50} \mathrm{H}_{54} \mathrm{Au}_{2} \mathrm{~N}_{2} \mathrm{O}_{2}: \mathrm{C}$ 54.16 (54.00); H 4.91 (5.01); N, 2.53 (2.59).

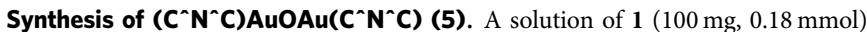
in dry acetone $(20 \mathrm{ml})$ was stirred for $16 \mathrm{~h}$ at $60^{\circ} \mathrm{C}$. The resulting precipitate was collected and was washed with acetone $(5 \mathrm{ml})$ and light petroleum $(5 \mathrm{ml})$ to give 5 as a yellow powder $(49 \mathrm{mg}, 50 \%)$. Crystals suitable for X-ray diffraction were obtained by layering a dichloromethane solution of $\mathbf{5}$ with light petroleum at $-25^{\circ} \mathrm{C} .{ }^{1} \mathrm{H}$ NMR $\left(300 \mathrm{MHz}, \mathrm{CD}_{2} \mathrm{Cl}_{2}\right) \delta 8.32(\mathrm{~d}, 2.0 \mathrm{~Hz}, 2 \mathrm{H}$, pyridyl), 7.77 $(\mathrm{t}, J=8.0 \mathrm{~Hz}, 1 \mathrm{H}$, pyridyl), $7.50(\mathrm{~d}, J=8 \mathrm{~Hz}, 2 \mathrm{H}$, phenyl), $7.41(\mathrm{~d}, 8.0 \mathrm{~Hz}, 2 \mathrm{H}$, phenyl), 7.20 (dd, $J=8,2 \mathrm{~Hz}, 2 \mathrm{H}$, phenyl), $1.08\left(\mathrm{~s}, 18 \mathrm{H},{ }^{\mathrm{t}} \mathrm{Bu}\right)$ (see Supplementary Fig. S16). $\left.{ }^{13} \mathrm{C}^{1} \mathrm{H}\right\}$ NMR $\left(75 \mathrm{MHz}, \mathrm{CD}_{2} \mathrm{Cl}_{2}\right) \delta 173.73\left(\mathrm{C}^{9}\right), 164.16\left(\mathrm{C}^{3}\right), 154.85\left(\mathrm{C}^{7}\right)$, $145.26\left(C^{4}\right), 141.33\left(C^{1}\right), 131.18\left(C^{8}\right), 124.16\left(C^{5}\right), 123.22\left(C^{6}\right), 115.57\left(C^{7}\right), 35.18$ $\left(\mathrm{C}^{10}\right), 30.80\left(\mathrm{C}^{11}\right)$. Anal. calcd. for $\mathrm{C}_{50} \mathrm{H}_{54} \mathrm{Au}_{2} \mathrm{~N}_{2} \mathrm{O}$ (found): $\mathrm{C} 54.95$ (55.03); H 4.98 (5.09); N, $2.56(2.66)$.

Synthesis of ( $\left.\mathbf{C}^{\wedge} \mathbf{N}^{\wedge} \mathbf{C}\right) \mathrm{AuO}^{t} \mathrm{Bu}$ (6). To $\left(\mathrm{C}^{\wedge} \mathrm{N}^{\wedge} \mathrm{C}\right) \mathrm{Au}\left(\mathrm{O}_{2} \mathrm{CCF}_{3}\right)(50 \mathrm{mg}, 0.08 \mathrm{mmol})$ and $4 \AA$ molecular sieves in a Schlenk tube was added a mixture of toluene and ${ }^{t} \mathrm{BuOH}(1: 1,10 \mathrm{ml})$. After stirring at room temperature for $12 \mathrm{~h}$, the volatiles were removed in vacuo and the residue was extracted with dichloromethane $(15 \mathrm{ml})$ and filtered. Removal of the solvent gave $\left(\mathrm{C}^{\wedge} \mathrm{N}^{\wedge} \mathrm{C}\right) \mathrm{AuO}^{t} \mathrm{Bu}$ as a deep yellow powder $(24 \mathrm{mg}, 50 \%) .{ }^{1} \mathrm{H}$ NMR $\left(300 \mathrm{MHz}, \mathrm{CD}_{2} \mathrm{Cl}_{2}\right) \delta 7.99\left(\mathrm{~d}, J=2 \mathrm{~Hz}, 2 \mathrm{H}, \mathrm{H}^{8}\right), 7.78$ $\left(\mathrm{t}, J=8 \mathrm{~Hz}, 1 \mathrm{H}, \mathrm{H}^{1}\right), 7.49\left(\mathrm{~d}, J=8 \mathrm{~Hz}, 2 \mathrm{H}, \mathrm{H}^{5}\right), 7.39\left(\mathrm{~d}, J=8 \mathrm{~Hz}, 2 \mathrm{H}, \mathrm{H}^{2}\right), 7.27$ (dd, $\left.J=8,2 \mathrm{~Hz}, 2 \mathrm{H}, \mathrm{H}^{6}\right), 1.49\left(\mathrm{~s}, 9 \mathrm{H}, \mathrm{OC}\left(\mathrm{CH}_{3}\right)_{3}\right), 1.38\left(\mathrm{~s}, 18 \mathrm{H}, \mathrm{H}^{11}\right)$ (see Supplementary Fig. S17). $\left.{ }^{13} \mathrm{C}^{1}{ }^{1} \mathrm{H}\right\}$ NMR $\left(75 \overline{\mathrm{MHz}}, \mathrm{CD}_{2} \mathrm{Cl}_{2}\right) \delta 171.79\left(\mathrm{C}^{9}\right), 164.67$ $\left(C^{3}\right), 154.43\left(C^{7}\right), 145.21\left(C^{4}\right), 142.20\left(C^{1}\right), 131.92\left(C^{8}\right), 124.24\left(C^{5}\right), 123.63\left(C^{6}\right)$, $115.87\left(\mathrm{C}^{2}\right), 74.24\left(\mathrm{OCMe}_{3}\right), 35.41\left(\mathrm{C}^{10}\right), 34.84\left(\mathrm{OCMe}_{3}\right), 30.97\left(\mathrm{C}^{11}\right)$. Anal. calcd. (found) for $\mathrm{C}_{29} \mathrm{H}_{36} \mathrm{AuNO}$ : C 56.95 (56.90), H 5.93 (5.85), N, 2.29 (2.33).

Synthesis of $\left(\mathbf{C}^{\wedge} \mathbf{N}^{\wedge} \mathbf{C}\right)$ AuOAc (9). A mixture of $\left(\mathrm{C}^{\wedge} \mathrm{N}^{\wedge} \mathrm{C}\right) \mathrm{AuCl}(152 \mathrm{mg}$, $0.349 \mathrm{mmol})$ and $\mathrm{AgOAc}(45 \mathrm{mg}, 0.384 \mathrm{mmol})$ in dichloromethane $(100 \mathrm{ml})$ was stirred at room temperature for $36 \mathrm{~h}$ in the dark. The precipitate of $\mathrm{AgCl}$ was filtered off and volatiles were removed in vacuo to yield $\left(\mathrm{C}^{\wedge} \mathrm{N}^{\wedge} \mathrm{C}\right) \mathrm{AuOAc}$ as a bright yellow powder $(196 \mathrm{mg}, 88 \%) .{ }^{1} \mathrm{H}$ NMR $\left(300 \mathrm{MHz}, \mathrm{CD}_{2} \mathrm{Cl}_{2}\right) \delta 7.85(\mathrm{t}$, $\left.J=8 \mathrm{~Hz}, 1 \mathrm{H}, \mathrm{H}^{1}\right), 7.54-7.45\left(\mathrm{~m}, 4 \mathrm{H}, \mathrm{H}^{8}+\mathrm{H}^{5}\right), 7.39\left(\mathrm{~d}, J=8 \mathrm{~Hz}, 2 \mathrm{H}, \mathrm{H}^{2}\right), 7.32$ $\left(\mathrm{dd}, J=8.2,2 \mathrm{~Hz}, 2 \mathrm{H}, \mathrm{H}^{6}\right), 2.34\left(\mathrm{~s}, 3 \mathrm{H}, \mathrm{OCOCH}_{3}\right), 1.38\left(\mathrm{~s}, 18 \mathrm{H}, \mathrm{H}^{11}\right)$ (see Supplementary Fig. S18). $\left.{ }^{13} \mathrm{C}^{1} \mathrm{H}\right\}$ NMR $\left(75 \mathrm{MHz}, \mathrm{CD}_{2} \mathrm{Cl}_{2}\right) \delta 174.25(\mathrm{O}=\mathrm{C})$, $169.50\left(C^{9}\right), 165.21\left(C^{3}\right), 155.22\left(C^{7}\right), 144.56\left(C^{4}\right), 143.15\left(C^{1}\right), 129.80\left(C^{8}\right), 124.82$ $\left(\mathrm{C}^{5}\right), 124.37\left(\mathrm{C}^{6}\right), 116.24\left(\mathrm{C}^{2}\right), 35.23\left(\mathrm{C}^{10}\right), 30.86\left(\mathrm{C}^{11}\right), 22.36\left(\mathrm{OCOCH}_{3}\right)$. Anal. calcd. (found) for $\mathrm{C}_{27} \mathrm{H}_{30} \mathrm{AuNO}_{2}$ : C 56.34 (56.45), H 5.67 (5.50), N 2.19 (2.31).

Kinetics of $\mathbf{0}$-abstraction from 1 with phosphines. Stock solutions of $\mathbf{1}$ (14.4 mM), $\mathrm{PR}_{3}(151 \mathrm{mM}$ ) and 18-crown-6 (internal standard, $300 \mathrm{mM}$ ) in toluene$d_{8}$ were prepared. To a solution of $1(0.5 \mathrm{ml}, 14.4 \mathrm{mM}, 7.2 \mu \mathrm{mol})$ in toluene- $d_{8}$ was added a solution of 18-crown- $6(20 \mu \mathrm{l}, 300 \mathrm{mM}, 6 \mu \mathrm{mol})$. The mixture was cooled at $-78^{\circ} \mathrm{C}$. Under light exclusion an appropriate amount of a pre-cooled solution of $(\mathrm{p} \text {-tolyl })_{3} \mathrm{P}(151 \mathrm{mM})$ was added. The NMR tube was briefly shaken before being inserted into the NMR probe, which was pre-cooled to the appropriate temperature. The reaction was monitored by ${ }^{1} \mathrm{H}$ NMR spectroscopy. Data points were collected at regular intervals (typically $120 \mathrm{~s}$, with $\mathrm{D} 1=1 \mathrm{~s}, \mathrm{AQ}=5.3 \mathrm{~s}$ and $\mathrm{NS}=16$ scans). Observed rates were determined under pseudo-first order conditions by monitoring the disappearance of the resonance of $\mathrm{H}^{8}$ for $\mathbf{1},(\delta=8.13)$, the increase of the resonance of $\mathrm{H}^{8}$ for $\left(\mathrm{C}^{\wedge} \mathrm{N}^{\wedge} \mathrm{C}\right) \mathrm{AuH} 8(\delta=8.40)$ and aromatic proton signals for $\mathrm{O}=\mathrm{P}(o \text {-tolyl })_{3}(\delta=7.79)$ versus the resonance of the internal standard $(\delta=3.51)$ (see Supplementary Figs S19,S20). Spectra were integrated automatically using the multi_integ3 command in TopSpin and the baseline correction was done manually. For details see Supplementary Methods.

\section{References}

1. Haruta, M., Kobayashi, T., Sano, H. \& Yamada, N. Novel Gold catalysts for the oxidation of carbon monoxide at a temperature far below $0{ }^{\circ} \mathrm{C}$. Chem. Lett. 16, 405-408 (1987).

2. Hutchings, G. J., Brust, M. \& Schmidbaur, H. Gold-an introductory perspective. Chem. Soc. Rev. 37, 1759-1765 (2008).

3. Hashmi, A. S. K. \& Hutchings, G. J. Gold catalysis. Angew. Chem. Int. Ed. 45, 7896-7936 (2006).

4. Chen, M. S. \& Goodman, D. W. Catalytically active gold on ordered titania supports. Chem. Soc. Rev. 37, 1860-1870 (2008).

5. Gimeno, M. C. \& Laguna, A. in: Comprehensive Coordination Chemistry II. vol. 6 (McCleverty, J. A. \& Meyer, T. J. eds) (Elsevier, 2003); p 911-1145.

6. Meyer, R., Lemire, C., Shaikhutdinov, S. K. \& Freund, H.-J. Surface chemistry of catalysis by gold. Gold Bull. 37, 72-124 (2004).

7. Parker, S. C. \& Campbell, C. T. Reactivity and sintering kinetics of Au/ $\mathrm{TiO}_{2}(110)$ model catalysts: particle size effects. Top. Catal. 44, 3-13 (2007).

8. Gao, Y. \& Zeng, X. C. Water-promoted $\mathrm{O}_{2}$ dissociation on small-sized anionic gold clusters. ACS Catal. 2, 2614-2621 (2012).

9. Yoon, B., Häkkinen, H. \& Landman, U. Interaction of $\mathrm{O}_{2}$ with gold clusters: molecular and dissociative adsorbtion. J. Phys. Chem. A 107, 4066-4071 (2003)

10. Weiher, N. et al. Activation of oxygen by metallic gold in $\mathrm{Au} / \mathrm{TiO}_{2}$ catalysis. J. Am. Chem. Soc. 129, 2240-2241 (2007).

11. Woodham, A. P., Meijer, G. \& Fielicke, A. Activation of molecular oxygen by anionic gold clusters. Angew. Chem. Int. Ed. 51, 4444-4447 (2012).

12. Woodham, A. P., Meijer, G. \& Fielicke, A. Charge separation promoted activation of molecular oxygen by neutral gold clusters. J. Am. Chem. Soc. 135, $1727-1730$ (2013).

13. Guzman, J. \& Gates, B. C. Catalysis by supported gold: correlation between catalytic activity for $\mathrm{CO}$ oxidation and oxidation states of gold. J. Am. Chem. Soc. 126, 2672-2673 (2004).

14. Hutchings, G. J. et al. Role of gold cations in the oxidation of carbon monoxide catalyzed by iron oxide supported gold. J. Catal. 242, 71-81 (2006).

15. Diaz-Morales, O., Calle-Vallejo, F., de Munck, C. \& Koper, M. T. M. Electrochemical water splitting by gold: evidence for an oxide decomposition mechanism. Chem. Sci. 4, 2334-2343 (2013).

16. Joshi, A. M., Delgass, W. N. \& Thomson, K. T. Partial oxidation of propylene to propylene oxide over a neutral gold trimer in the gas phase: a density functional theory study. J. Phys. Chem. B 110, 2572-2581 (2006).

17. Bobuatong, K. et al. Aerobic oxidation of methanol to formic acid on $\mathrm{Au}_{20}^{-}$: a theoretical study on the reaction mechanism. Phys. Chem. Chem. Phys. 14, 3103-3111 (2012).

18. Howard, K. L. \& Willock, D. J. A periodic DFT study on the activation of $\mathrm{O}_{2}$ by Au nanoparticles on $\alpha-\mathrm{Fe}_{2} \mathrm{O}_{3}$. Faraday Discuss. 152, 135-151 (2011).

19. Nesmeyanov, A. N. et al. Tris(triphenylphosphinegold)oxonium salts. J. Organomet. Chem. 201, 343-349 (1980).

20. Chung, S.-C., Krüger, S., Schmidbaur, H. \& Rösch, N. A density functional study of trigold oxonium complexes and of their dimerization. Inorg. Chem. 35, 5387-5392 (1996).

21. Yang, Y. \& Sharp, P. R. New gold clusters $\left[\mathrm{Au}_{8} \mathrm{~L}_{6}\right]\left(\mathrm{BF}_{4}\right)_{2}$ and $\left[(\mathrm{AuL})_{4}\right]\left(\mathrm{BF}_{4}\right)_{2}$ $\left(\mathrm{L}=\mathrm{P}(\text { mesityl })_{3}\right.$. J. Am. Chem. Soc. 116, 6983 (1994)

22. Ramón, R. S. et al. $\left[\{\mathrm{Au}(\mathrm{IPr})\}_{2}(\mu-\mathrm{OH})\right] \mathrm{X}$ Complexes: synthetic, structural and catalytic studies. Chem. Eur. J. 17, 1238-1246 (2011).

23. Cinellu, M. A. et al. The first gold (III) dinuclear cyclometallated derivatives with a single oxo bridge. Chem. Commun. 2397-2398 (1998). 
24. Cinellu, M. A. et al. $\mu$-Oxo and alkoxo complexes of gold(III) with 6-alkyl-2,2' bipyridines. Synthesis, characterisation and X-ray structures. J. Chem. Soc. Dalton Trans. 1735-1741 (1998).

25. Cinellu, M. A. et al. Reactions of gold(III) oxo complexes with cyclic alkenes. Angew. Chem. Int. Ed. 44, 6892-6895 (2005).

26. Schroeder, D. et al. Large effect on small substitution: competition of dehydration with charge retention and coulomb explosion in gaseous $\left[\left(\text { bipy }^{\mathrm{R}}\right) \mathrm{Au}(\mu-\mathrm{O})_{2}\left(\text { bipy }^{\mathrm{R}}\right)\right]^{2+}$ dications. J. Am. Chem. Soc. 131, 13009-13019 (2009).

27. Cinellu, M. A. et al. $\left[\mathrm{Au}_{2}\left(\mathrm{phen}^{2 \mathrm{Me}}\right)_{2}(\mu-\mathrm{O})_{2}\right]\left(\mathrm{PF}_{6}\right)_{2}$, a novel dinuclear gold(III) complex showing excellent antiproliferative properties. ACS Med. Chem. Lett. 1, 336-339 (2010).

28. Cinellu, M. A. et al. Gold(III) derivatives with anionic oxygen ligands: mononuclear hydroxo, alkoxo and acetato complexes. Crystal structure of $\left[\mathrm{Au}(\mathrm{bpy})(\mathrm{OMe})_{2}\right]\left[\mathrm{PF}_{6}\right]$. Dalton Trans. 1261-1265 (2000).

29. Messori, L. et al. Gold(III) complexes with bipyridyl ligands: solution chemistry, cytotoxicity, and DNA binding properties. J. Med. Chem. 45, 1672-1677 (2002).

30. Messori, L. et al. Structural and solution chemistry, antiproliferative effects and DNA and protein binding properties of a series of dinuclear gold(III) compounds with bipyridyl ligands. J. Med. Chem. 49, 5524-5531 (2006).

31. Bortoluzzi, M., De Faveri, E., Daniele, S. \& Pitteri, B. Synthesis of a new tetrakis (2-pyridinyl)pyrazine complex of gold(III) and its computational, spectroscopic and electrochemical characterization. Eur. J. Inorg. Chem. 3393-3399 (2006).

32. Roşca, D.-A., Smith, D. A. \& Bochmann, M. Cyclometallated gold(III) hydroxides as versatile synthons for $\mathrm{Au}-\mathrm{N}, \mathrm{Au}-\mathrm{C}$ complexes and luminescent compounds. Chem. Commun. 48, 7247-7249 (2012).

33. Smith, D. A., Roșca, D.-A. \& Bochmann, M. Selective Au-C cleavage in $\left(\mathrm{C}^{\wedge} \mathrm{N}^{\wedge} \mathrm{C}\right) \mathrm{Au}(\mathrm{III})$ aryl and alkyl pincer complexes. Organometallics 31, 5988-6000 (2012)

34. Roşca, D.-A., Smith, D. A., Hughes, D. L. \& Bochmann, M. A Thermally stable gold(III) hydride: synthesis, reactivity, and reductive condensation as a new route to $\mathrm{Au}^{\mathrm{II}}$ complexes. Angew. Chem. Int. Ed. 51, 10643-10646 (2012).

35. Savjani, N., Roșca, D.-A., Schormann, M. \& Bochmann, M. Gold(III) olefin complexes. Angew. Chem. Int. Ed. 52, 874-877 (2013).

36. Boisvert, L. \& Goldberg, K. I. Reactions of late transition metal complexes with molecular oxygen. Acc. Chem. Res. 45, 899-910 (2012).

37. Denney, M. C., Smythe, N. A., Cetto, K. L., Kemp, R. A. \& Goldberg, K. I. Insertion of molecular oxygen into a palladium(II) hydride bond. J. Am. Chem. Soc. 128, 2508-2509 (2006).

38. Wick, D. D. \& Goldberg, K. I. Insertion of dioxygen into a platinum-hydride bond to form a novel dialkylhydroperoxo Pt(IV) complex. J. Am. Chem. Soc. 121, 11900-11901 (1999).

39. Boisvert, L., Denney, M. C., Hanson, S. K. \& Goldberg, K. I. Insertion of molecular oxygen into a palladium(II) methyl bond: a radical chain mechanism involving palladium(III) intermediates. J. Am. Chem. Soc. 131, 15802-15814 (2009).

40. Grice, K. A. \& Goldberg, K. I. Insertion of dioxygen into a platinum(II)-methyl bond to form a platinum(II) methylperoxo complex. Organometallics 28, 953-955 (2009).

41. Ozerov, O. V. et al. Reactivity of a $\mathrm{Pd}(\mathrm{I})-\mathrm{Pd}(\mathrm{I})$ dimer with $\mathrm{O}_{2}$ : monohapto $\mathrm{Pd}$ superoxide and dipalladium peroxide in equilibrium. J. Am. Chem. Soc. 133, 3820-3823 (2011).

42. Strukul, G., Ros, R. \& Michelin, R. A. Preparation and oxygen-transfer properties of novel palladium(II) and platinum(II) hydroperoxo and alkylperoxo complexes. Inorg. Chem. 21, 495-500 (1982).

43. Jacox, M. E. NIST Chemistry WebBook, NIST Standard Reference Database Number 69. (eds Linstrom, P. J. \& Mallard, W. G.) (National Institute of Standards and Technology 20899, 2011) http://webbook.nist.gov.
44. Yeo, B. S. et al. Identification of hydroperoxy species as reaction intermediates in the electrochemical evolution of oxygen on gold. ChemPhysChem 11, 1854-1857 (2010).

45. Chem. Soc. Rev. 42 themed issue 6 2205-2472 (2013)

46. Du, P. \& Eisenberg, R. Catalysts made of earth-abundant elements (Co, Ni, Fe) for water splitting: recent progress and future challenges. Ener. Environ. Sci. 5, 6012-6021 (2012).

47. Hetterscheid, D. G. H. \& Reek, J. N. H. Mononuclear water oxidation catalysts. Angew. Chem. Int. Ed. 51, 9740-9747 (2012).

48. Cao, R., Lai, W. \& Du, P. Catalytic water oxidation at single metal sites. Ener. Environ. Sci. 5, 8134-8157 (2012).

49. Kohl, S. W. et al. Consecutive thermal $\mathrm{H}_{2}$ and light-induced $\mathrm{O}_{2}$ evolution from water promoted by a metal complex. Science 324, 74-77 (2009).

50. Gomez-Gallego, M. \& Sierra, M. A. Kinetic isotope effects in the study of organometallic reaction mechanisms. Chem. Rev. 111, 4857-4963 (2011).

51. Exner, O. Correlation Analysis of Chemical Data, Plenum Press, 1988; p 61-62.

52. Luo, X., Fleming, P. R. \& Rizzo, T. R. Vibrational overtone spectroscopy of the $4 v_{\mathrm{OH}}+v_{\mathrm{OH}}$, combination level of $\mathrm{HOOH}$ via sequential local mode-local mode excitation. J. Chem. Phys. 96, 5659-5667 (1992).

53. Barker, J. R., Benson, S. W. \& Goldem, D. M. The decomposition of dimethylperoxide and the rate for $\mathrm{CH}_{3} \mathrm{O}+\mathrm{O}_{2} \rightarrow \mathrm{CH}_{2} \mathrm{O}+\mathrm{HO}_{2}$. Int. J. Chem. Kinet. 9, 31-53 (1977).

54. Coles, S. J. \& Gale, P. Changing and challenging times for service crystallography. Chem. Sci. 3, 683-689 (2012).

55. Martinho Simoes, J. A. \& Beauchamp, J. L. Transition metal-hydrogen and metal-carbon bond strengths: the keys to catalysis. Chem. Rev. 90, 629-688 (1990).

\section{Acknowledgements}

This work was supported by the Leverhulme Trust and Johnson Matthey plc. D.A.R thanks the University of East Anglia for a studentship. We are grateful to the National Crystallographic Service, University of Southampton, for data collection of complexes 3 4 and 5. DFT calculations were performed using the High-Performance Computing Cluster supported by the Research and Specialist Computing Support Service at the University of East Anglia. We thank Dr Vasily Oganesyan for providing access to computational facilities.

\section{Author contributions}

M.B. conceived and supervised the study and wrote the manuscript. D.A.R. carried out the experiments. D.-A.R. and D.L.H. performed the X-ray crystallography. J.A.W. contributed the computational section.

\section{Additional information}

Accession codes: The X-ray crystallographic coordinates for structures reported in this Article (see Supplementary Table 2) have been deposited at the Cambridge Crystallographic Data Centre (CCDC), under deposition numbers CCDC 936989 (2), CCDC 936992 (3), CCDC 936990 (4), CCDC 936991 (5), CCDC 936993 (9) (ref. 54). These data can be obtained free of charge from the Cambridge Crystallographic Data Centre via www.ccdc.cam.ac.uk/data_request/cif.

Supplementary Information accompanies this paper at http://www.nature.com/ naturecommunications

Competing financial interests: The authors declare no competing financial interests.

Reprints and permission information is available online at http://npg.nature.com/ reprintsandpermissions/

How to cite this article: Roșca, D.-A. et al. Gold peroxide complexes and the conversion of hydroperoxides into gold hydrides by successive oxygen-transfer reactions. Nat. Commun. 4:2167 doi: 10.1038/ncomms3167 (2013). 